Bufa-Dörr Zsuzsanna, Izsák Bálint, Sebestyén Ágnes, Róka Eszter, Khayer Bernadett, Bártfai Boglárka, Vargha Márta

Nemzeti Népegészségügyi Központ

National Public Health Center

DOI: https://doi.org/10.29179/EgTud.2020.4.6-29

\title{
Kis ivóvízellátó rendszerek és magánkutas ivóvízellátás egészségkockázata
}

\section{Health risks of small-scale drinking water supply systems and private wells}

\section{Összefoglalás}

Az európai régióban a lakosság 23\%-ának ivóvízellátását közösségi vagy magán ellátást biztosító kis ivóvízellátó rendszer biztosítja. Magyarországon az ivóvízellátás 95\%-a közműves ellátásból származik, azonban a lakosság közel 40\%-át (kb. 4 millió fő) kis vízellátó rendszerek látják el, 3\%-ot tesz ki az egyedi, nem közműves ellátás (pl. kis lakóközösségek, tanyák, régi mezőgazdasági vagy ipari telepek), a lakosság fennmaradó 2\%-ának ivóvizét pedig magánkutak biztosítják. A Nemzeti Népegészségügyi Központ (NNK) által kezelt adatbázisok elemzésével értékeltük a kis és nagy ivóvízellátó rendszerek, valamint a magánkutakjellemző vízminőségének különbségeit. A kis (5000 főnél kevesebbet kiszolgáló) ivóvízellátó rendszerekben a nagyobb arányban kifogásolt vízminőség minden vizsgált paraméter vonatkozásában azonosítható, azonban fokozottan a másodlagos vízminőségromlást jelző mikrobiológiai paraméterek, úgymint coliform baktéri- 
umok, telepszám $22^{\circ} \mathrm{C}$-on, illetve a geológiai eredetű kémiai paraméterek, mint az arzén, a bór, a vas és a mangán tekintetében. Az NNK Környezetegészségügyi Vizsgáló Laboratóriumában vizsgált magánkutak vízminőségi adatai alapján a kútvizek minősége mikrobiológiai, elsősorban fekális szennyezők és kémiai, például nitrát tartalom, növényvédőszerek mennyisége következtében változatos, fogyasztásuk jelentős közegészségügyi kockázatot jelenthet.

Kulcsszavak: kis vízellátó rendszer, magánkút, vízminőség

\section{Abstract}

In the European region 23\% of the population relies on small public or private water supply systems for drinking water. In Hungary, 95\% of the drinking water supply comes from public utilities, however, $40 \%$ of the population (approximately 4 million people) is supplied by small water supply systems. 3\% are individual, not public community utilities (e.g. small housing estates, homesteads, old agricultural or industrial sites), and the remaining 2\% of the population is supplied by private wells. We analysed the differences in the characteristic water quality of small and large water supply systems and private wells by analysing data from databases managed by the National Public Health Center (NPHC). In small water supply systems (serving less than 5,000 people), lower compliance in water quality could be identified for all examined parameters but more significantly for microbiological parameters mainly related to failures or secondary contamination such as coliform bacteria, colony count at $22^{\circ} \mathrm{C}$, and geological chemical parameters such as arsenic, boron, iron and manganese. According to the water quality data tested in the Environmental Health Laboratory of the NPHC, the quality of the well waters varied due to microbiological, mainly faecal contaminants and chemical parameters, for example nitrate and pesticides.

Keywords: drinking water, small-scale water supply system, private well, water quality 
Környezetegészségügy - Eredeti közlemény / Environmental health - Original article

\section{EGÉSZSÉGTUDOMÁNY}

$2020 ; 64(4): 6-29$

\section{HEALTH SCIENCE}

Közlésre érkezett: 2020. március 10.

Submitted:10 March 2020

Elfogadva: 2020. július 30.

Accepted: 30 July 2020

Levelezési cím/Correspondence:

Bufa-Dörr Zsuzsanna

Nemzeti Népegészségügyi Központ 1097 Budapest, Albert Flórián út 2-7.

E-mail: dorr.zsuzsanna@nnk.gov.hu

Tel.: +361476-1212 házi ivóvízhálózat, jellemzően magánkutas ellátás) ivóvízellátást is. Éppen ezért a kis ivóvízellátó rendszerekkel összefüggő egészségkockázat értékelésére nemzetközi szinten is egyre nagyobb hangsúly kerül. Az Egészségügyi Világszervezet (továbbiakban: WHO) több tanulmányt is készített a kis ivóvízellátó rendszerek működésével és tapasztalataival kapcsolatosan, valamint ezek fejlesztési lehetőségeit számos útmutatóban és nemzetközi konferencián elemezte ?.

\section{Kis ivóvízellátó rendszerek Európában}

Európában nincs egységes definíció a kis ivóvízellátó rendszerekre, és ezáltal a különböző országokban a szabályozás és a vizsgálati kötelezettségek is jelentős eltéréseket mutatnak. Az Európai Unió tagállamai a kis és nagy ivóvízellátó rendszereket vagy az ellátott lakosság alapján (jellemzően 5000 fő alatti, illetve feletti) vagy a termelt vízmennyiség alapján (jellemzően 1000 m³/nap alatt, illetve felett) különítik el, illetve az adott országban jellemző keretek között az 
Környezetegészségügy - Eredeti közlemény / Environmental health - Original article

üzemeltetési struktúra alapján (magán vagy közösségi) is megkülönböztetik 1,2. Az adatok a különböző kategorizálás miatt nehezen összehasonlíthatóak, és az egységes elemzést tovább nehezíti, hogy számos tagállamban nincs a kis ivóvízellátó rendszerek mindegyikére nézve kötelező vízvizsgálati rendszer, valamint hogy a legtöbb tagállamban nemzeti szinten nincs teljeskörü, részletes adatgyűjtés a kis vízellátó rendszerek számára, vizsgálatára, vízminőségére vonatkozóan '. Az ivóvíz minőségére vonatkozó Európai Uniós Irányelv (98/83/ EC) hatálya az 50 fö alatti ivóvízellátó rendszerekre - ha azok nem közösségi vagy kereskedelmi ellátást biztosítanak - nem terjed $\mathrm{ki}^{3}$.

A kis ivóvízellátó rendszerek aránya a tagállamok között nagy különbséget mutat. Ausztriában a lakosság 32\%ának ivóvizét kis ivóvízellátó rendszerek biztosítják, míg Horvátországban 1,6\% a kis közösségi vízellátás aránya és 10,6\% a magánkutas ellátás. Csehországban kimagaslóan magas, 90\% feletti $(93,4 \%)$ a kis ivóvízellátó rendszerekből (magán vagy közösségi) származó ivóvízellátás aránya. Németországban a lakosság 11\%-a fogyaszt 5000 főnél kevesebb lakost ellátó vízellátó rendszerből, és 0,7\%a magánkútból ivóvizet. Romániában a lakosság egyharmadának nincs közmüves ivóvízellátása, ők jellemzően a magánkutas ellátásra támaszkodnak ?

A WHO adatgyűjtéseit összefoglaló tanulmányok alapján az Európai Unió tagországai az alábbi területeken azonosítottak problémákat a kis ivóvízellátó rendszerek vonatkozásában:

- szabályozatlanság, vagy ha van is jogszabályi előírás, annak betartatási nehézségei; kisszámú (vagy sok esetben hiányzó) kötelező vízminőség vizsgálat és emiatt adathiány;

- pénzügyi nehézségek (monitoring, karbantartás, képzés, beavatkozási intézkedések, fejlesztések területén), amit tovább nehezítenek a fajlagosan (fogyasztóra számítva) magas beruházási, üzemeltetési és karbantartási költségek;

- rendszer szinten elfogadott roszszabb vízminőség, a nagy - jellem- 
Környezetegészségügy - Eredeti közlemény / Environmental health - Original article

zően 5000 fő feletti lakosságot ellátó - ivóvízellátó rendszerekhez képest;

- szennyezett (kommunális és mezőgazdasági szennyezés), vagy ismeretlen minőségü (gyakran a forrás is ismeretlen) nyersvíz, sérülékeny vízbázisok használatának kényszerüsége;

- hiányzó vagy alacsony színvonalon üzemeltetett vízkezelő technológia, beleértve a fertőtlenítést is;

- alacsonyabb színvonalú management és üzemeltetési szakértelem, magánkutak esetén ennek teljes hiánya;

- alacsonyabb politikai prioritás, pénzügyi támogatás a kisebb lobbi erő miatt is;

- ingadozó vízhasználatból eredő kockázatok pl. évszakos változások;

- jelenleg már érzékelhető, vagy a jövőben várható vízhiány;

- tisztázatlan tulajdonlási viszonyok, illegális múködés (jellemzően magánkutak esetén) $1,2,4,5,6,7$.

A WHO és az Egyesült Nemzetek Szervezete (ENSZ) az ivóvízhez való hozzáférés szintjének követésére a globális
JMP (Joint Monitoring Programme) felmérés keretében bevezette a fejlesztett ivóvízellátás fogalmát, ami természetes módon vagy technológia által védett ivóvízforrást jelent. Bár fejlesztett ivóvízellátásnak minősül a vezetékes vízellátás mellett már a közkút, a védett ásott kút, a csőkút, a forrás, valamint a megfelelően kivitelezett esővíz gyüjtés is, ennek ellenére a WHO felmérése alapján a világ lakosságának 13\%-a nem fejlesztett (pl. nem védett kutak és források, felszíni víz) ellátásból jut ivóvízhez. A vidéki lakosság kb. 4\%-a számára nem is érhető el fejlesztett ivóvízforrás, míg a városi lakosságnál ez az arány csak 0,6\% 2,8 .

Bármely besorolás alapján vizsgáljuk a kis ivóvízellátó rendszereket, a használatuk üzemeltetési- és egészségkockázata minden vizsgált országban meghaladja a nagyokét.

Az Európai Unió tagállamaiban a kis vízellátó rendszerekre vonatkozó mikrobiológiai megfelelőség $40 \%$ és 100\% között mozog, míg az 500-5000 fő közötti vízellátó rendszerekben a meg- 
Környezetegészségügy - Eredeti közlemény / Environmental health - Original article

felelőség jellemzően 90\% feletti. Skóciában az 50 fő alatti vízellátást biztosító rendszerek mikrobiológiai megfelelősége a fekális szennyezést jelző E. coli baktérium esetén 40\% alatti, míg az 500-5000 fő közötti vízellátó rendszerek esetén $78 \%{ }^{8}$. Fehéroroszországban a kis vízellátó rendszerekből szolgáltatott ivóvíz nem-megfelelősége mikrobiológiai paraméterek alapján 30,1\%, a kémiai paraméterek alapján 14,5\%. Kémiai paraméterek közül elsősorban a nitrit, a nitrát, az arzén, a vas és a mangán okoz problémát. 90\% alatti megfelelőség ammónium, nitrát és/vagy nitrit paraméter tekintetében pl. Horvátország, Dánia, Észtország, Lettország, Románia, Szlovénia, fluorid paraméter tekintetében Észtország és Szlovénia, arzén tekintetében Magyarország, nátrium tekintetében Málta, míg vas és mangán tekintetében Horvátország, Dánia, Észtország, Lettország, Magyarország, Románia, Szlovákia és az Egyesült Királyság kis vízellátó rendszereiben jelentkezett ${ }^{4}$.

\section{Saját célú ivóvízmüvel történő (ma- gánkutas) ivóvízellátás}

A magánkutak a kis közműves ivóvízellátáshoz képest is nagyobb kockázatot jelentenek. Az EU tagállamaiban nagyon változó a saját célú ivóvízműre támaszkodó lakosok aránya. Litvániában a lakosság kb. 25\%-a fogyasztja csak az egy-egy család ellátását biztosító magánkút vizét. Skóciában a magánkútból származó vizet fogyasztók aránya 3\%, míg Macedóniában 6,4\%. Csehországban kb. 750.000 magánkút található, melyet a lakosok ivóvízellátás, rekreációs tevékenységek, nyaralók vízellátása céljából használnak. Németországban kb. 750.000 fő vízellátását biztosítja a mintegy 185.000 magánkút. Finnországban a lakosság 10\%-a használ magánkutakat, a vidéki hétvégi házakban ez a fő vízellátási mód ².

A magánkutas ivóvízellátásban jellemzően kis mélységü kutakat (30200 m) és sekély mélységú kutakat (30 m-nél kisebb mélységűek), illetve ritkábban közepes mélységú kutakat (200-500 m) használnak. A kutak kiala- 
kításuk alapján lehetnek ásott vagy aknás, fúrt illetve vert kutak. Az ásott kutak falát téglával vagy betongyürúkkel rakják ki, mélységük pedig némileg a talajvíz-tükör alá hatol, kizárólag a felső talajvíz összegyüjtésére alkalmasak. Vízszintjük ingadozó, nagyban befolyásolja a lehulló csapadék, ezért a víz utántöltődése lassú, a száraz nyári időszakban pedig nem ritka, hogy a kút kiszárad. Tárolókapacitásuk általában 0,5-2 köbméter közötti. Ezek a kutak a környezetükben folyó intenzív mezőgazdasági tevékenység - főként a mútrágyázás - miatt könnyen elszennyeződhetnek (pl. nitráttal). A fúrt kút egy speciális fúró berendezéssel a földbe mélyített bélelt furat, amelynek a mélysége az átmérőjéhez képest nagy. A fúrt kút lehet mindössze néhány méter vagy akár 120 méter mély is, a felhasználás céljától függően. A fúrt kút gyűjtheti a felsőbb talajrétegekben a talajvizet, vagy a mélyebben fekvő rétegvizet. Nagy előnye, hogy folyamatos vízadásra képes, akár napi több 100 köbméteres mennyiségben is. A kútfej zárt, ezért külső szennyeződések nehezebben juthatnak be, a vizet pedig jellemzően szivattyúval lehet a felszínre hozni. A magánkutak vízminőségére potenciális szennyezőforrásként a mezőgazdasági szennyezés (diffúz növényvédőszer szennyezés), az állattartás, kommunális szennyezés, ipari szennyezés van leginkább káros hatással (1. ábra).

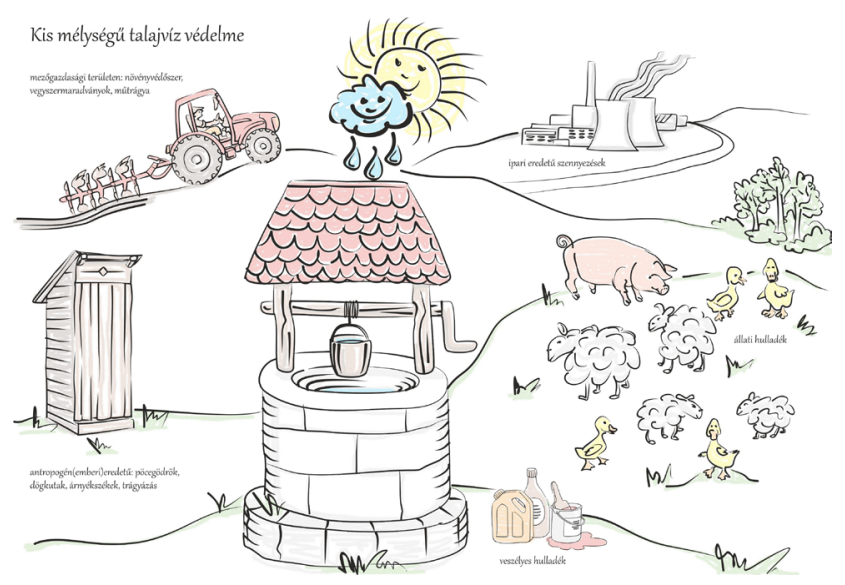

1. ábra: A nyersvíz kockázatai a kis mélységú talajvízkutak vonatkozásában (saját grafika)

Figure 1. Risk factors associated with the raw water of shallow groundwater wells lown graphic)

A magánkutak vízminősége világszerte változó, a fő mikrobiológiai problémát a fekális eredetű szennyezők jelentik, de a mezőgazdasági szennyezést jelző nitrát és a növényvédőszerek 
Környezetegészségügy - Eredeti közlemény / Environmental health - Original article

miatti nem-megfelelőség is gyakori. A geológiai eredetű szennyezők közül az arzén emelhető ki. Skóciában 1750 vízminta alapján a magánkutak vízminőségének nem-megfelelősége 30\% E. coli paraméter, $41 \%$ coliform baktériumok és $15 \%$ nitrát paraméter vonatkozásában. Macedóniában a magánkutak mikrobiológiai nem-megfelelősége 30\%. Az Amerikai Egyesült Államokban 44 millió magánkút használóból 2 millió fő fogyasztja határérték (10 $\mu \mathrm{g} / \mathrm{l})$ feletti arzéntartalmú kút vizét ${ }^{2}$.

\section{Kockázatcsökkentés, elérhető jó gya-}

\section{korlatok a kis vízellátó rendszerek vo- natkozásában}

A WHO kapcsolódó tanulmányait elemezve egyértelmüen megállapítható, hogy az ivóvízminőség-felügyeletben a kockázat alapú módszerek alkalmazásával biztosítható leghatékonyabban az ivóvíz eredetű egészségkockázatok csökkentése. A kockázat alapú rendszerek alapja minden esetben egy részletes veszélyelemzés és kockázatértékelés a fogyasztó egészségére gyakorolt hatás szempontjából, végigvezetve a teljes ivóvízellátó rendszeren a vízbeszerzéstől a fogyasztói pontig, ami lehetővé teszi a megelőzés elve alapján meghatározott vízminőség felügyeletet és a szükséges javító beavatkozások tervezését. A WHO elérhető tanulmányai hangsúlyozzák, hogy a koncepció kiterjesztése a kis ivóvízellátó rendszerekre kiemelten fontos, bár mindenképpen egy nagyon egyszerű felépítésű rendszer kidolgozása javasolt, mely kellően pontosan azonosítja a legfontosabb kockázatokat, azok felügyeletére megfelelő, de egyszerű monitoring rendszert dolgoz ki, azonban nem jelent elfogadhatatlanul nagy adminisztratív és költségterhet az üzemeltetőknek ${ }^{4,5}$.

Az Európai Bizottság 24 tagállam között végzett 2017. évi felmérése alapján a legtöbb tagállam a kis ivóvízellátó rendszerek üzemeltetésében a kockázat alapú megoldások alkalmazását, illetve a kötelező, de egyszerúsített jogi követelmények előírását tartja a leghatékonyabbnak a kockázatok csökkentésére (2. ábra). 
Környezetegészségügy - Eredeti közlemény / Environmental health - Original article

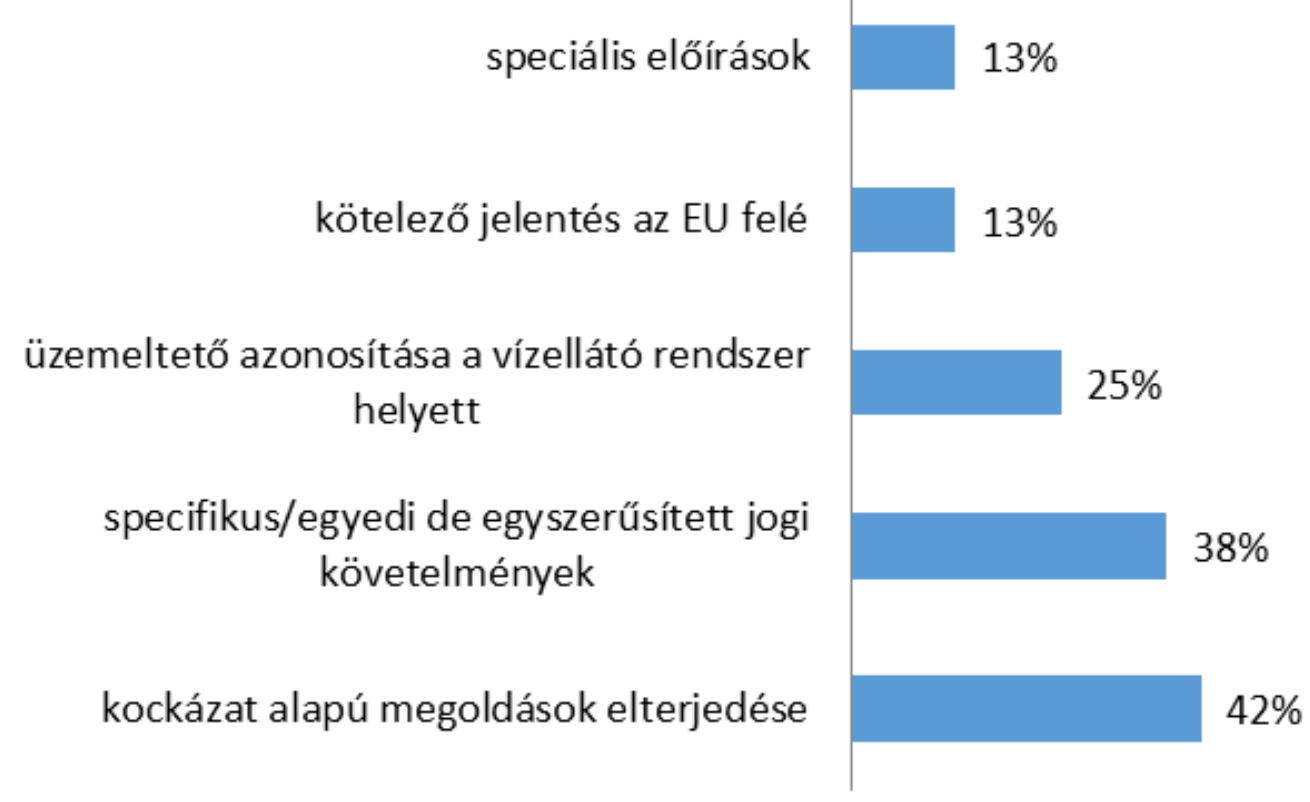

2. ábra: Lehetséges megoldások a kis vízellátó rendszerek esetén az ivóvízellátás kockázatainak csökkentésére a válaszadó tagállamok arányával (saját szerkesztés ${ }^{9}$ )

Figure 2. Possible solutions to reduce the risks associated with drinking water supply from small systems as a percentage of the responding Member States (based on ${ }^{9}$ )

Számos „jó gyakorlat” müködik a különböző országokban a kis vízellátó rendszerek, illetve a magánkutas ellátásból származó kockázatok csökkentésére. Írországban pl. az EPA (Environmental Protection Agency) a magánkút használatainak kockázatairól és a kockázatcsökkentési lehetőségekről kampányt indított, melynek keretében létrehoztak egy webes alkalmazást („Protect your well App” http://erc.
epa.ie/water/wel/s/\#.XpVu3PozaUk), valamint útmutatókat, videót, infografikákat, televíziós és közösségi média reklámokat, szórólapokat/plakátokat készítettek. Németországban munkacsoport alakult a kis ivóvízellátó rendszerek vízminőségének fejlesztésére, amely különböző ismeretterjesztő füzetek és iránymutatások révén segíti, támogatja a magánkutak üzemeltetőit és a helyi közegészségügyi ható- 
Környezetegészségügy - Eredeti közlemény / Environmental health - Original article

ságokat. Az Egyesült Királyságban a DWI (Drinking Water Inspectorate) 2012-ben kifejlesztett egy Excel-alapú eszközt a kis vízellátó rendszerek kockázatértékelésére, amely a honlapjukon bárki számára hozzáférhető. Skóciában a magánkutakat üzemeltetők számára támogatási rendszer müködik, mely a szükséges fejlesztések, vízminőség-javító beruházások finanszírozására használható $(2,4,5,6,7,8)$.

\section{Célkitüzés}

A cikkben összefoglaljuk a kis vízellátó rendszerek és a magánkutas vízellátás vízminőségi és vízellátási adatait, és értékeljük ezek ivóvízellátásban történő alkalmazásának közegészségügyi kockázatait.

\section{Anyagok és módszerek}

A kis ivóvízellátó rendszerek és a magánkutas ellátásra vonatkozó monitoring, vízminőség ellenőrzési és üzemel- tetési adatokat az alábbi adatforrások feldolgozásával elemeztük:

- A kis ivóvízellátó rendszerek vízminőségi és vízellátási adatait az NNK által kezelt ivóvíz-minőségi adatbázis (Humán felhasználású vizek informatikai rendszere, továbbiakban: HUMVI) adatai ${ }^{10}$, valamint az ezen alapuló, az NNK által összeállított, 2014-2016 évekre vonatkozó Európai Unió számára készített ország-jelentés alapján elemeztük. Az értékelésben összehasonlítottuk a kis (5000 fő alatti) és a nagy (5000 fő feletti) vízellátó rendszerek ivóvízminőségi adatait " 1 .

- A kis ivóvízellátó rendszerek nyersvizeire, valamint vízkezelésére vonatkozó adatokat az NNK által végzett, a geológiai eredetű fémek vízbázisokban való mennyiségének felmérését célzó vizsgálat eredményei alapján értékeltük ${ }^{12}$.

- A hazai jogi szabályozásnak 2009 óta része a kockázat alapú üzemeltetés (ivóvízbiztonsági tervezés) követelménye, mely a legkisebb (50 fönél több fogyasztót ellátó) vízellátó 
Környezetegészségügy - Eredeti közlemény / Environmental health - Original article

rendszerekre is kiterjesztésre került. Az NNK az ivóvízbiztonsági tervek megfelelőségéről közegészségügyi szempontú szakvéleményt állít ki. Az NNK ezen szakvélemények tartalmi és formai megfelelőségét 2019-ben összefoglalóan értékelte. A kis ivóvízellátók kockázat alapú rendszereinek megfelelőségét az NNK által az ivóvízbiztonsági tervekre vonatkozó adatai alapján értékeltük ${ }^{13}$.

- Az NNK Környezetegészségügyi Vizsgáló Laboratóriuma (továbbiakban: NNK-KVL) megrendelésre végzi magánkutak vízminőség-ellenőrzését. A hazai magánkutak vízminőségét az NNK-KVL 2015-2020 között végzett kútvízvizsgálatok adatai alapján értékeltük. 2018 óta a vizsgálatok mellett a kutat használókkal egy a kockázati tényezőkre, valamint az üzemeltetés körülményeire vonatkozó egyszerü adatlapot is kitöltetünk. A kockázatfelmérő adatlap a felhasználás módjára (csak dísznövények öntözése, fogyasztásra szánt zöldségek, gyümölcsök öntözése, medence feltöltése vagy ivóvíz is), a kút elhelyezkedése (kiemelt helyen, vagy a kút felé lejt a terület; épületben, épület alatt vagy az udvaron, kertben helyezkedik el stb.) vonatkozóan tartalmaz kérdéseket. Rákérdez továbbá, hogy történik-e vízkezelés és/vagy fertőtlenítés, és ha igen, milyen technológiával, valamint, hogy a kút 10, illetve 100 méteres környezetében milyen potenciális szennyezőforrások azonosíthatók (pl. mezőgazdasági terület, állattartás, trágya/hígtrágya elhelyezés, kommunális hulladék lerakás, árnyékszék) ${ }^{14}$.

\section{Eredmények}

Magyarországon az ivóvízellátás 95\%-a közmúves ellátásból származik, azonban a lakosság közel 40\%-át (kb. 4 millió fő) kis vízellátó rendszerek látják el. Körülbelül 3\%-ot tesz ki az egyedi, nem közműves ellátás (pl. kis lakóközösségek, tanyák, régi mezőgazdasági vagy ipari telepek), a lakosság fennmaradó 2\%-ának vízellátását pedig magánkutak biztosítják (3. a) és b) ábra). 


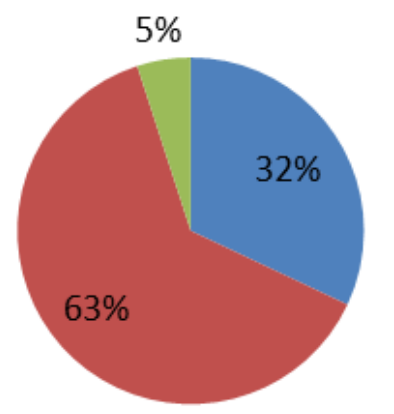

- Nagyon kis vízellátó
rendszer 500 fổ alatt Kis vízellátó rendszer 500-5000 fổ

- Nagy vízellátó rendszer 5000 fổ felett

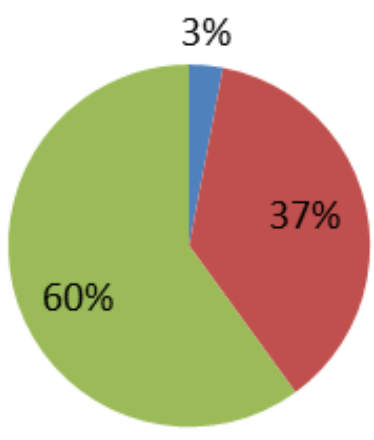

- Nagyon kis vízellátó rendszer 500 fổ alatt

Kis vízellátó rendszer 500-5000 fố

Nagy vízellátó rend szer 5000 fổ felett

\section{3. ábra: Különböző méretű ivóvízellátó}

rendszerek aránya a rendszerek száma (a), és az általuk ellátott lakosszám (b) alapján Magyarországon (saját szerkesztés ${ }^{10,11,12}$ )

Az országos ivóvízminőségi adatbázis adatai alapján végzett elemzésünk szerint a nagyon kis (100 m³/nap-nál kevesebb vizet termelő) vízellátó rendszerek száma 538 db, melyek megközelítőleg 320.000 fő vízellátását biztosítják ${ }^{10}$.

A kis ivóvízellátó rendszerek vízminősége az európai tapasztalatokhoz hasonlóan hazánkban is kedvezőtle-
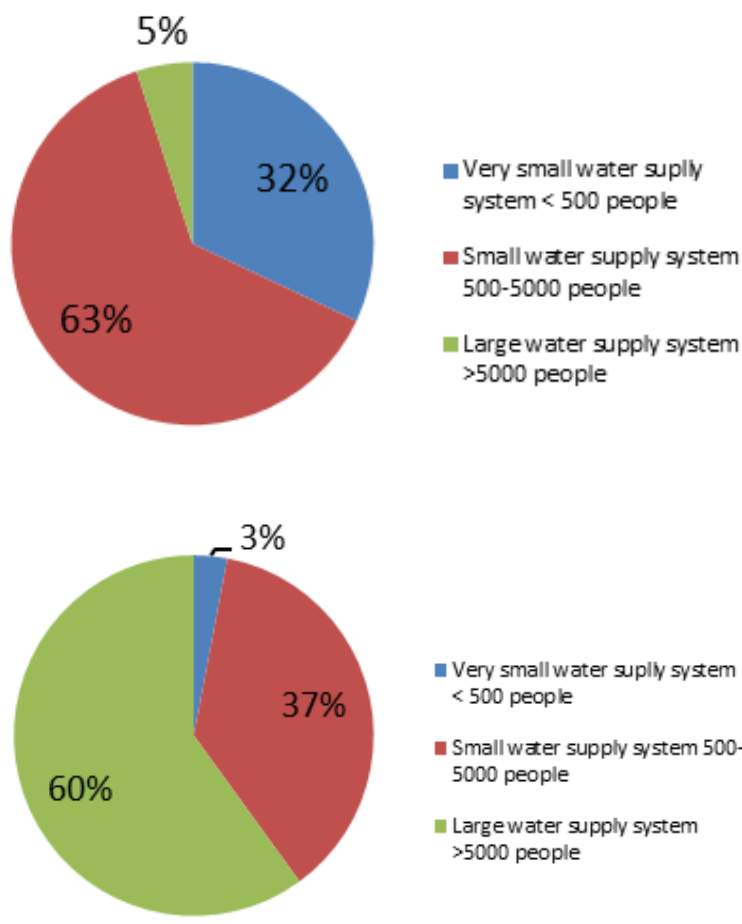

Figure 3. Ratio of drinking water supply systems of different size by the number of systems (a) and the number of supplied people (b) in Hungary (based on own drawing ${ }^{10,11,12}$ )

nebb, mint a nagyoké (ahol az ellátott lakosszám 5000 fő feletti), mind kémiai, mind mikrobiológiai paraméterek tekintetében is. A vízminőségben tapasztalható különbség a 2016. évi EU felé küldött országjelentés eredményeit elemezve is megállapítható, melyet a 4. és 5. ábra is szemléltet. A nagyobb arányban kifogásolt vízminőség minden vizsgált paraméter vonatko- 
zásában azonosítható, azonban kifejezetten megfigyelhető a mikrobiológiai paraméterek, úgymint coliform baktériumok és telepszám $22^{\circ} \mathrm{C}$-on, illetve a geológiai eredetú kémiai paraméterek, mint az arzén, a bór, a vas és a mangán tekintetében. A víziközmú szolgáltatók adatszolgáltatásán alapuló, a nagyon kis vízellátó rendszerekben üzemelő vízkezelő technológiákra vonatkozó fo- lyamatban lévő felmérésünk alapján a nagyon kis vízellátó rendszerek közel fele jelenleg vízkezelő technológia nélkül üzemel, és közel 40\%-ukban fertőtlenítés sincs.

A kis ivóvízellátó rendszerek mikrobiológiai minősége az elmúlt években nem változott jelentősen, ezt az alábbi ábra is szemlélteti (6. ábra).

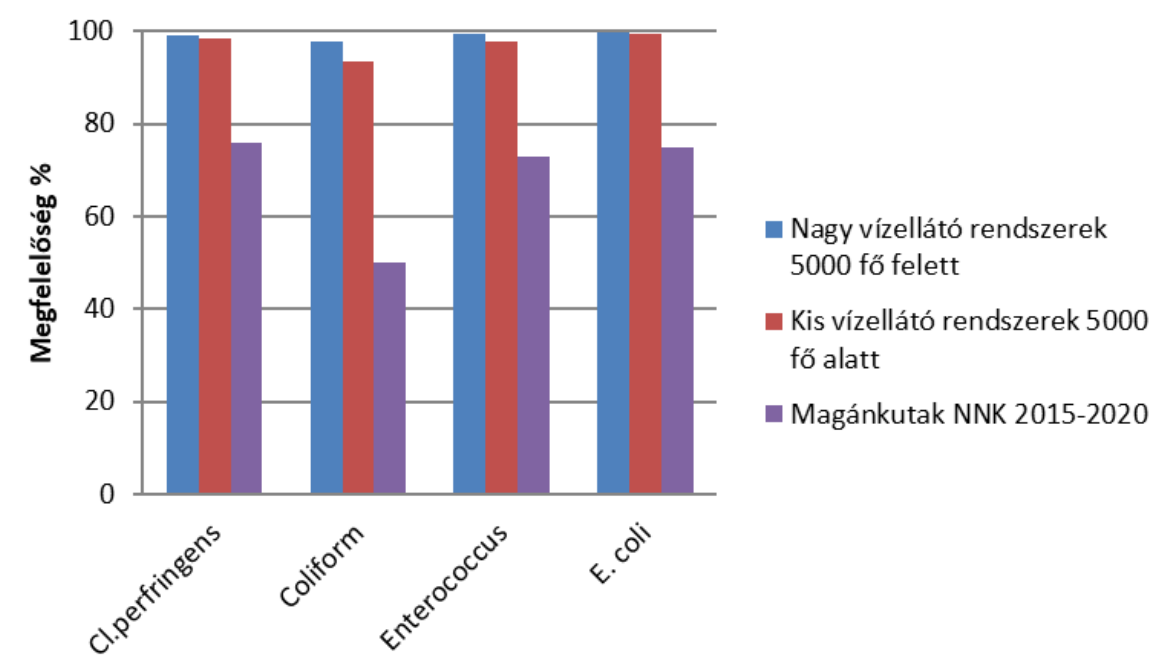

4. ábra: A kis és a nagy ivóvízellátó rendszerek, valamint magánkutak mikrobiológiai vízminőségének összehasonlítása: megfelelő minták aránya az összes vizsgált minta \%-ában (saját szerkesztés $10,11,14)$ 
Környezetegészségügy - Eredeti közlemény / Environmental health - Original article

\section{Compliance \%}
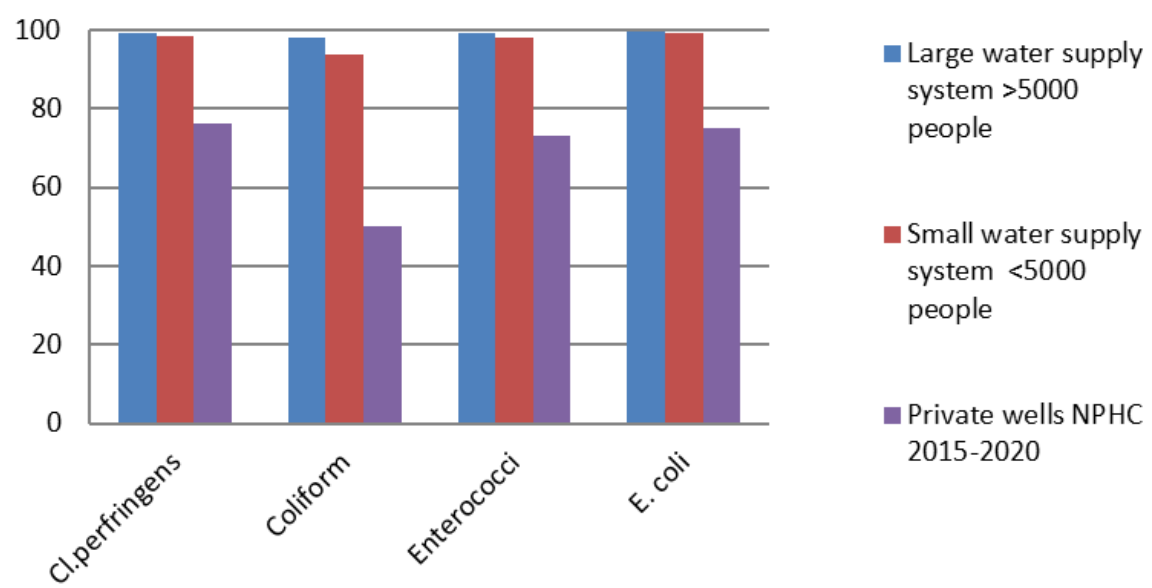

Figure 4. Comparison of microbiological compliance of drinking water supplied from small and large drinking water supply systems and private wells (based on own drawing ${ }^{10,11,14}$ )

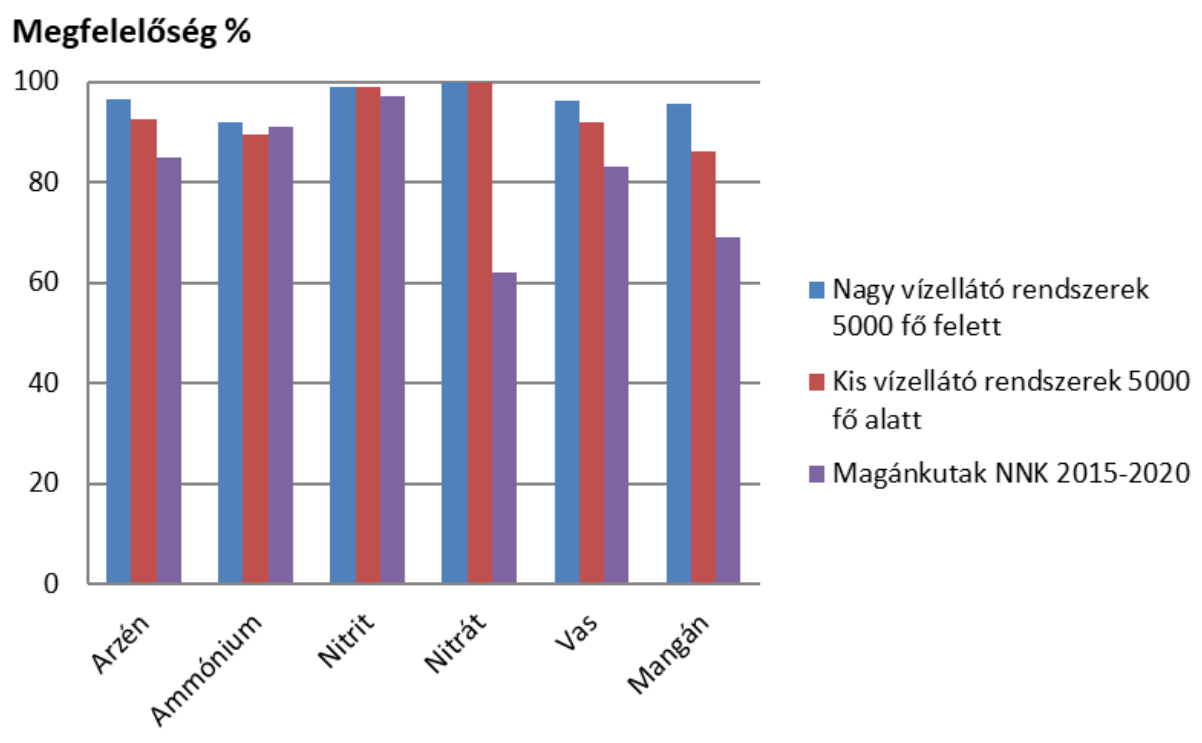

5. ábra: A kis és a nagy ivóvízellátó rendszerek, valamint magánkutak kémiai vízminőségének összehasonlítása (saját szerkesztés ${ }^{10,11,14}$ ) 


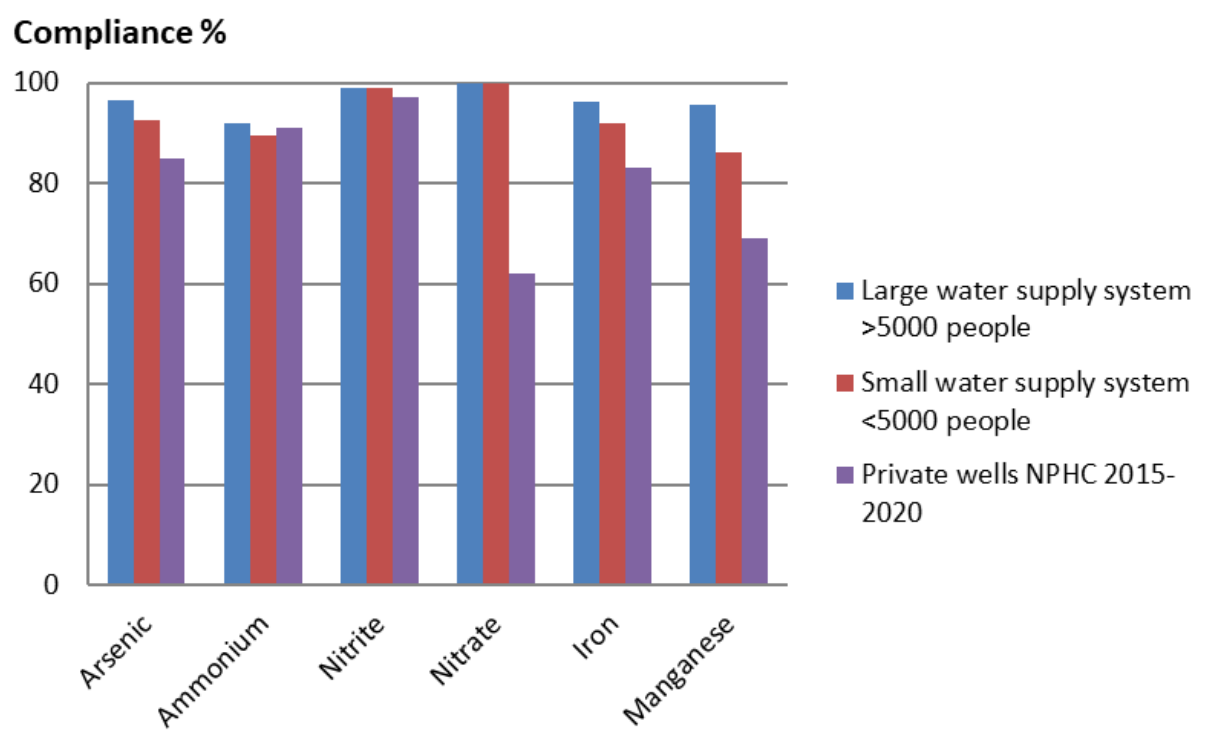

Figure 5. Comparison of chemical compliance of drinking water supplied from small and large water supply systems and private wells (based on own drawing ${ }^{10,11,14}$ )

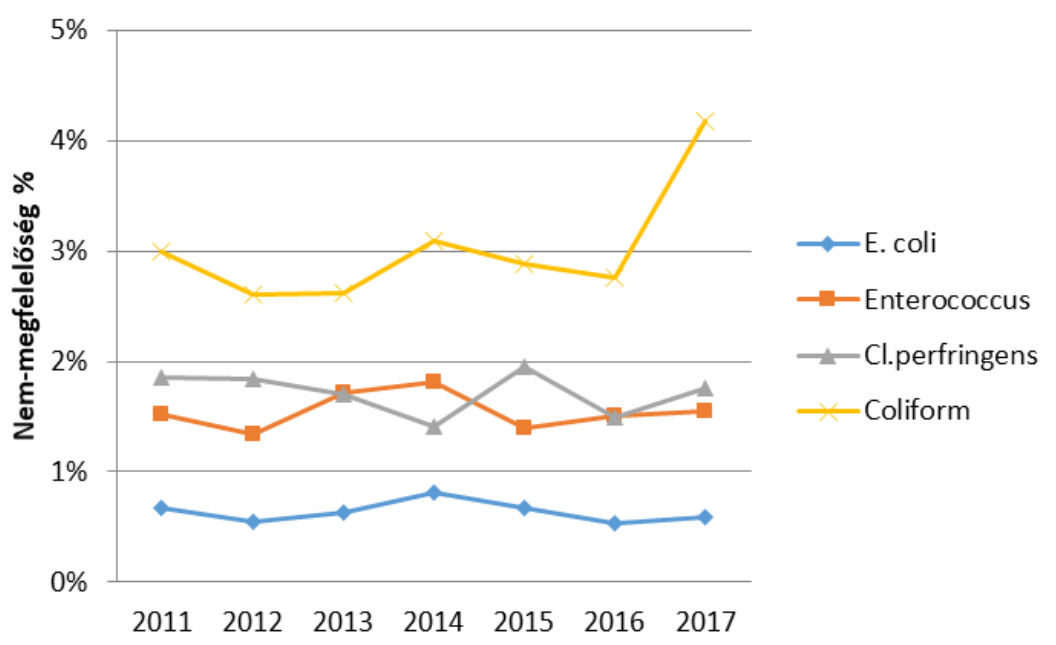

6. ábra: Kis ivóvízellátó rendszerek mikrobiológiai vízminőségének változása 2011-2017 között Magyarországon: kifogásolt minták aránya az összes vizsgált minta \%-ában (saját szerkesztés ${ }^{10}$ ) 
Környezetegészségügy - Eredeti közlemény / Environmental health - Original article

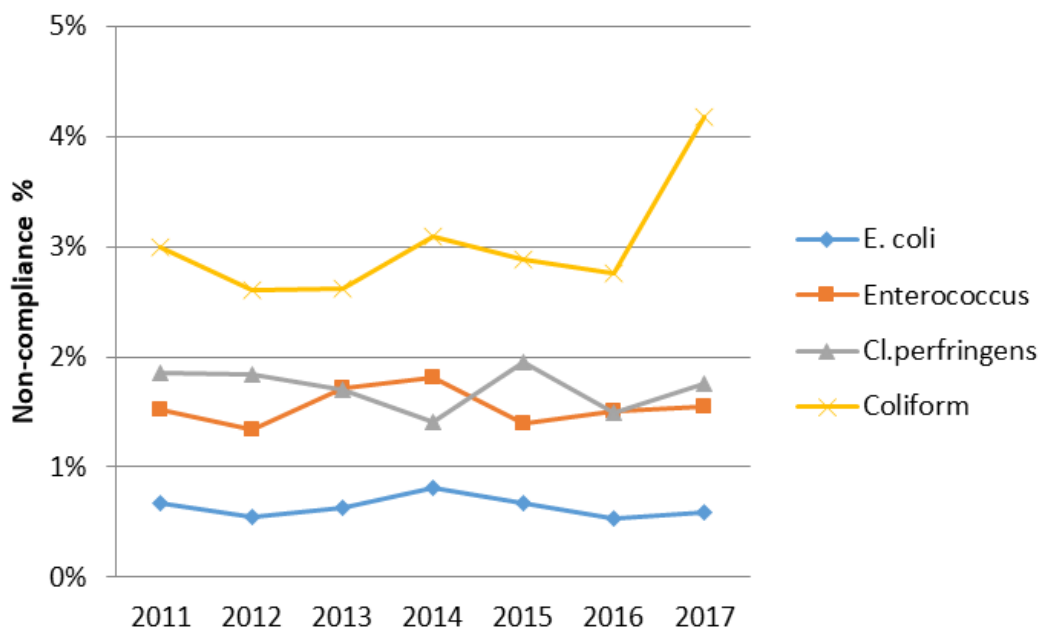

Figure 6. Changes in microbiological non-compliance of the water from small drinking water supply systems between 2011 and 2017 in Hungary (based on own drawing 10)

A 201/2001. (X.25.) Kormányrendelet alapján Magyarországon minden 50 főnél több állandó lakost ellátó, illetve több mint $10 \mathrm{~m}^{3} / \mathrm{hap}$ vízmennyiség felett szolgáltató ivóvízellátók üzemeltetőinek veszélyelemzésen és kockázatértékelésen alapuló rendszereiket ivóvízbiztonsági tervben kell rögzíteniük. A követelmény az ivóvízellátó rendszerek mérete alapján halasztott hatálylyal került bevezetésre. A jóváhagyási folyamat kétlépcsős: 1) először a Nemzeti Népegészségügyi Központ szakmai véleményében elemzi, hogy a vízbiztonsági terv szerinti müködés elősegíti-e az üzemeltetésből származó közegészség- ügyi kockázatok mérséklését; 2) ezt követően a tervek hatósági elfogadását az illetékes kormányhivatalok népegészségügyi főosztályai és a járási hivatalok népegészségügyi osztályai végzik. Az ivóvízbiztonsági tervek alapja egy átfogó veszélyelemzés és kockázatértékelés a fogyasztó egészségére gyakorolt hatás szempontjából, végigvezetve az ivóvízellátási lánc minden elemén, valamint kiegészítve a kockázatok megelőzésére és csökkentésére alkalmas megelőző és helyesbítő tevékenységekkel ${ }^{15}$.

Az NNK közegészségügyi szempontú szakvéleményeinek adatait gyűj- 
töttük össze és értékeltük. Az értékelést 1500 ivóvízellátó rendszerre vonatkozóan végeztük el, melyek közül közel 1400 kis ivóvízellátó rendszer volt, beleértve 120 nem közműves, egyedi ivóvízellátót is. Az ivóvízbiztonsági tervek minősége mind tartalmi, mind formai szempontból nagyon sokszínü, a megfelelőségük értékelését országos szinten (kis és nagy vízellátó rendszerekre vonatkozóan is) elvégeztük. Az ivóvízbiztonsági tervek tartalmi megfelelősége az értékelésünk alapján nem a vízellátó rendszer méretétől függ elsősorban, hanem az üzemeltető által használt módszertan megfelelőségén, az évek során felgyűlt tapasztalatok megfelelő beépítésén múlik. Általános tapasztalat a vízellátó rendszer méretétől függetlenül, hogy az ivóvízbiztonsági tervekben a vízbázis védettségére vonatkozó adatok és ezzel összefüggően a sérülékeny vízbázisok kockázatértékelése hiányos, továbbá gyakran elnagyolt a nyersvíz minőségével, az eseti, illetve a hálózaton történő utólagos vízkezeléssel összefüggő, valamint az érzékeny és időszakos fogyasztók, valamint az idegenkezúségből és a szélsőséges időjárásból adódó veszélyek értékelése. A vízellátás főbb lépéseire vonatkozóan elvégzett veszélyelemzés- és kockázatértékelés megfelelőségét a 7. ábra tartalmazza.

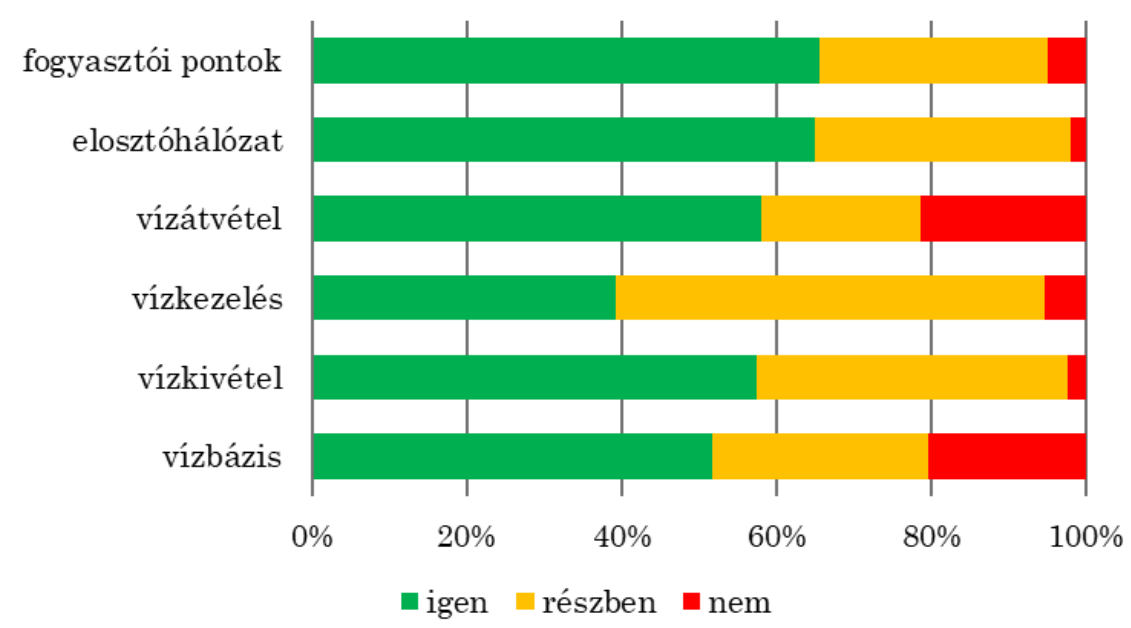

7. ábra: A veszélyelemzés- és kockázatértékelés megfelelősége vízellátási lépésenként az NNK szakvélemények értékelése alapján, $n=1500$ (saját szerkesztés ${ }^{13}$ ) 
Környezetegészségügy - Eredeti közlemény / Environmental health - Original article

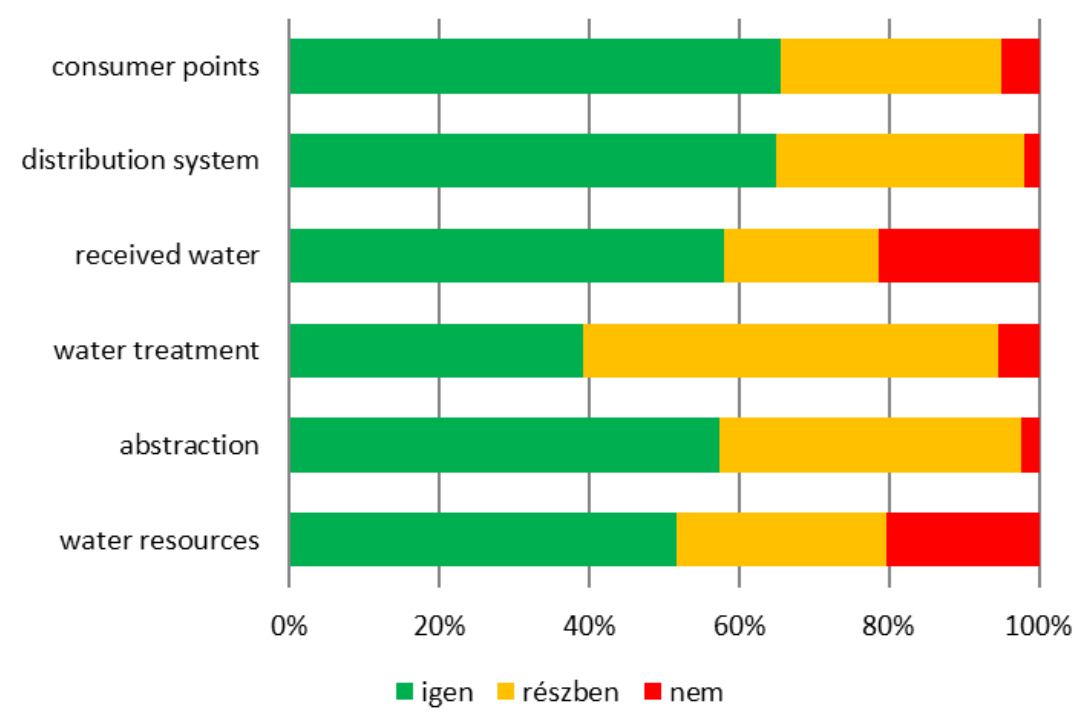

Figure 7. Suitability of the hazard analysis and risk assessments by water supply steps based on the evaluation of NPHC expert opinions, $n=1500$ (based on own drawing ${ }^{13}$ )

Magyarországon az ivóvízellátás céljára szolgáló saját célú ivóvízművek (lényegében magánkutak) létesítése a 147/2010. (IV.29.) Kormányrendelet alapján (kapacitástól függően) bejelentés vagy engedélyköteles tevékenység, azonban becslések szerint a kutak 95\%a illegálisan üzemel. Létesítéskor és azt követően 3 évente a szennyezést jelző paraméterekre vonatkozó vízminőség ellenőrzését is jogszabály írja elő. A vizsgálandó paraméterek köre szükebb, mint a közmúves ivóvízellátás esetében (szín, szag, íz, zavarosság, hőmérséklet, E. coli, coliform baktériumok, telepszám
$22{ }^{\circ} \mathrm{C}$-on, Enterococcus, pH, fajlagos elektromos vezetőképesség, ammónium, nitrit, nitrát, összes keménység, klorid, szervesanyag tartalom (KOIps), vas, mangán, lúgosság, fertőtlenítéssel összefüggő paraméterek), de a tulajdonosok többsége nem tud erről a kötelezettségről ${ }^{16}$.

Jelenleg sem a népegészségügyi, sem a vízügyi hatóságoknál, szakmai szervezeteknél nincs információ arra vonatkozóan, hogy országos szinten menynyi és milyen vízminőségü kutat használnak ivóvízellátásra, így az ebből eredő, 
Környezetegészségügy - Eredeti közlemény / Environmental health - Original article

fogyasztókat érő egészségkockázat sem ítélhető meg. A vonatkozó jogszabály szerint a kutak vízminőségének értékelését, valamint nem-megfelelőség esetén a szükséges beavatkozások elrendelését a népegészségügyi hatóságok végzik, azonban a kútfúrások feltételezett számához képest 2019-ben elenyésző számú megkeresés érkezett hozzájuk, és a kutak vízminőségi eredményeiről jellemzően nem is áll rendelkezésre adat a népegészségügyi hatóságnál.
A magánkutak vízminősége és üzemeltetési gyakorlata az NNK-KVL saját vizsgálatai alapján is rendkívül változatos. 2015 és 2020 között 205 magánkút vizsgálatát végeztük el. A vizsgált kutak elsősorban Budapest és Pest megye területén helyezkedtek el, így az eredmények országosan nem tekinthetők reprezentatívnak (8. ábra).

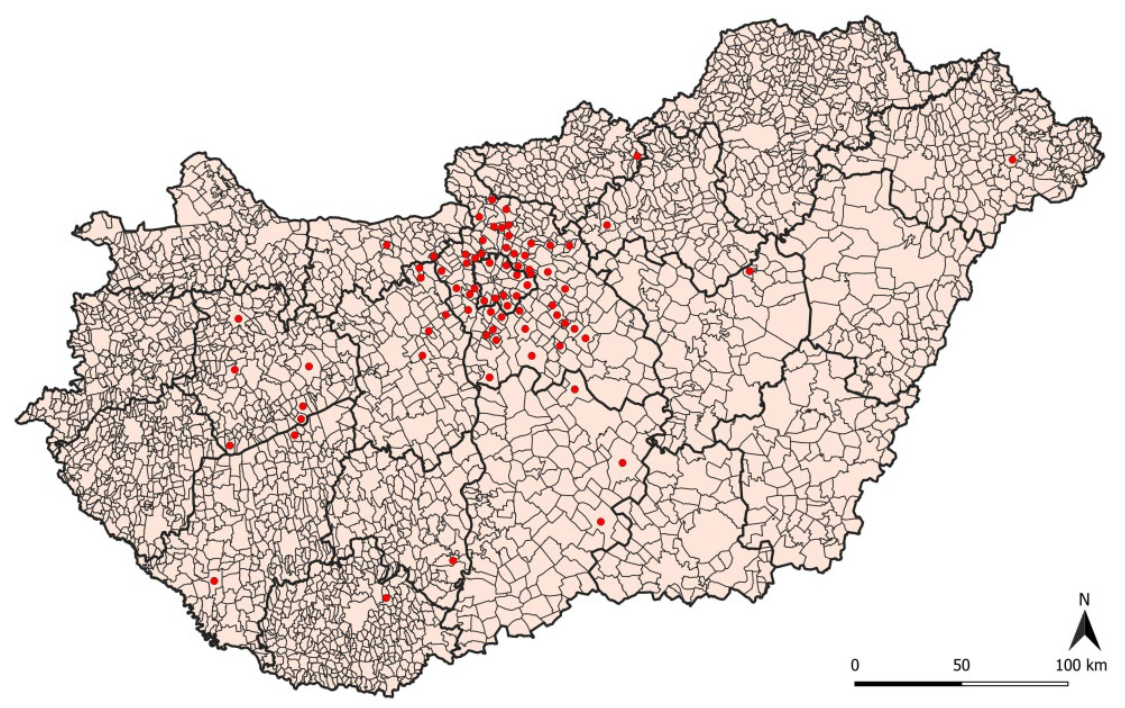

8. ábra: A Nemzeti Népegészségügyi Központ Környezetegészségügyi Vizsgáló Laboratóriumába által vizsgált kutak elhelyezkedése (saját szerkesztés ${ }^{14}$ )

Figure 8. Location of the private wells analysed in the Environmental Health Laboratory of the NPHC (based on own drawing ${ }^{14}$ ) 
Környezetegészségügy - Eredeti közlemény / Environmental health - Original article

Az eredményeink alapján önbevallásuk szerint a magánkutak vizét használók közel fele nincs tisztában a használat kockázataival, illetve aki igen, az is évi egynél ritkábban vagy soha sem ellenőrizteti a kútvíz minőségét. Egyetlen válaszadó sem számolt be a kútvíz fogyasztásával, felhasználásával összefüggésbe hozott azonosított megbetegedésről. A kutakat jellemzően elkülönített helyen telepítették, csak kb. 10\%-uk esetén szennyezett annak környezete, vagy nincs megoldva az állati eredetü szennyezéstől való védelmük. A tulajdonosok a kutak müszaki állapotára, típusára, mélységére vonatkozóan szinte egyáltalán nem rendelkeztek biztos ismerettel. Vízkezelés jellemzően nem történt, de ahol igen, ott egyedileg a kútvíz minőségére tervezett vízkezelő berendezés helyett általános volt az ivóvíz utótisztító kisberendezések használata, annak ellenére, hogy ezek alkalmazása jelenleg kútvíz-kezelésre nem vizsgált és nem is engedélyezett. Állandó fertőtlenítésről egyetlen válaszadó tulajdonos sem számolt be. A kút környezetében lévő potenciális szenynyezőforrásokról - különösen a tágabb környezet vonatkozásában - jellemzően nem szolgáltattak adatot, így a szennyezők hatásának csökkentésére vélhetően nem tesznek semmilyen intézkedést. $A$ vizsgálati eredmények alapján (4. és 5. ábra) a kutak egyharmadának a mikrobiológiai vízminősége nem volt megfelelő, vizükből fekális szennyezést jelző baktérium (E. coli vagy Enterococcus) volt kimutatható. A vizsgált kútvizek közel 40\%-ában a nitrát koncentrációja meghaladta a határértéket (50 mg/l). A kutak 20, illetve 15\%-ában dezetil-atrazin, illetve atrazin növényvédőszer volt kimutatható, továbbá dikamba, fenoxi ecetsav, MCPA és dezizopropil-atrazin is előfordult. Azon minták esetén, ahol a növényvédőszer-maradék volt kimutatható, 75\%-ban a nitrát paraméter is meghaladta a határértéket, amely azt támasztja alá, hogy a mezőgazdasági eredetű szennyezés jelzésére a nitrát paraméter vizsgálata megfelelő lehet.

\section{Eredmények értékelése, diszkusszió}

A kis és a nagy vízellátó rendszerek vízminőségében azonosított egyértelmü különbség - a nemzetközi tapasztala- 
Környezetegészségügy - Eredeti közlemény / Environmental health - Original article

tokhoz hasonlóan - a másodlagos vízminőségromlással összefüggő paraméterek vonatkozásában elsősorban az elöregedett hálózatokkal és a csökkenő vízhasználás miatti pangó, alacsony áramlási sebességú szakaszok kialakulásával magyarázható, míg a geológiai eredetű kémiai paraméterek vonatkozásában a hiányzó, vagy nem megfelelő hatékonysággal üzemeltetett vízkezelő technológiákkal függ össze.

A kis vízellátó rendszerek vízminőségében mérhető javulás a kockázat alapú üzemeltetés elterjedésétől és különösen a másodlagos vízminőségromlással összefüggésbe hozható mikrobiológiai és kémiai paraméterek esetében egy átfogó hálózatrekonstrukciós program lefolytatásától lenne várható. Az ivóvízbiztonsági tervezés szemléletének üzemeltetési gyakorlatba történő átültetése időigényes, az ivóvízellátó rendszerek, különösen a kis ivóvízellátó rendszerek nagy részében még nem valósult meg teljes körüen, ezáltal eredményük a mikrobiológiai minőség alakulásában még nem látható. A kis ivóvízellátó rendszerek kémi- ai vízminőségének javulása a nyersvíz eredetű szennyező anyagok esetében jellemzően csak vízkezelő technológia kiépítésével, optimalizálásával vagy másik ivóvízellátó rendszerre való csatlakozással valósítható meg.

A Nemzeti Népegészségügyi Központban 2015-2020 között vizsgált magánkút eredményeket értékelve megállapítható, hogy a magánkutak vízminősége elsősorban a mikrobiológiai paraméterek, valamint a nitrát, a vas és a mangán paraméterek tekintetében lényegesen rosszabb, mint akár a kis, akár a nagy közmúves ellátásból származó ivóvízé. A kútvizek fogyasztása a várandósok és 3 év alatti kisgyermekek számára methemoglobinémiás betegség miatt kockázatot jelent. A magánkutak bizonytalan vízminőségét, és az abból eredő közegészségügyi kockázatát elsősorban a védettségük hiányából származó mikrobiológiai paraméterek, valamint a nitrát és az arzén paraméterek okozzák. A felhasználók ismerete a magánkutak kockázataira, illetve a lehetséges kockázatcsökkentő beavatkozásokra vonatkozóan hiányos, így a 
kútvízfogyasztásból származó kockázat csökkentését egy átfogó tájékoztató, valamint a fokozottan érzékeny csoportok (várandósok, kisgyermeket nevelők) esetében egy lehetséges vizsgálatokat is támogató program segíthetné.

\section{Következtetések}

Az NNK által kezelt, jelen kutatás során felhasznált adatbázisok eredményeit értékelve a kis ivóvízellátó rendszerek (5000 fő alatti) és a magánkutas vízellátás közegészségügyi kockázata a nemzetközi tapasztalatokhoz hasonlóan meghaladja a nagy (5000 fő feletti) ivóvízellátó rendszerekét. Emiatt fontos, hogy mind a vízellátás, mind a közegészségügy szakemberei fokozottan figyeljenek ezekre a vízellátó rendszerekre. A kis és különösen a nagyon kis (100 m³/nap alatti) ivóvízellátó rendszerek vízminőségében a másodlagos vízminőségromlással összefüggő paraméterek vonatkozásában a legnagyobb az elmaradás, amiben csak komplex, átfogó és hosszú távú meg- oldások, mint például egy átfogó hálózatrekonstrukciós program, kockázat alapú üzemeltetés mindennapi gyakorlatba való átültetése hozhat mérhető javulást. A magánkutak használata, különösen ivóvíz célú hasznosítása jelentős kockázatot jelent, mely új, valamint a jelenleg is érvényes jogszabályi előírások betartatása mellett (regisztrációs kötelezettség, vízminőség-ellenőrzés követelménye) intenzív lakossági tájékoztatással lenne mérsékelhető.

\section{Nyilatkozatok}

A szerzők nyilatkoznak arról, hogy a közlemény más folyóiratban korábban nem jelent meg, és máshová beküldésre nem került. A szerzők nyilatkoznak arról is, hogy a cikk végleges változatát valamenynyi szerző elolvasta és jóváhagyta.

\section{Szerzök hozzájárulása}

B.D.Zs.: a kézirat elkészítése; I.B.: a kézirat szakmai ellenőrzése; S.Á.: a 
Környezetegészségügy - Eredeti közlemény / Environmental health - Original article

kézirat szakmai ellenőrzése; RE: a kézirat szakmai ellenőrzése; K.B.: a kézirat szakmai ellenőrzése; B.B.: a kézirat szakmai ellenőrzése; V.M.: a kézirat szakmai ellenőrzése

\section{Anyagi támogatás}

A közlemény megírása, illetve az ehhez kapcsolódó kutatómunka anyagi támogatásban nem részesült.

\section{Szerzői érdekeltségek}

A szerzőknek nincsenek a tartalmat érintő érdekeltségeik.

\section{Irodalomjegyzék}

1. Meeting report on Subregional workshop on improving small-scale water supplies for better health in European Union member states 2018.06.18-20 Dessau, https://www.euro.who.int/__data/assets/pdf file/0020/392231/REPORT-10-edited-final. $\underline{p d f}$
2. WHO Small-scale water supplies in the pan-European region, ISBN 978928900226 4 (2011) https://www.euro.who.int/en/publications/abstracts/small-scale-water-supplies-in-the-pan-european-region.-background.-challenges.-improvements

3. 98/83/EC Irányelv, https://eur-lex.europa.eu/legal-content/HU/TXT/? uri=CELEX\%3A31998L0083 (Megtekintés: 2020.04.06.)

4. WHO Status of small-scale supplies in the WHO European Region, ISBN 97892890 51941 (2012) https://www.euro.who.int/en/ publications/abstracts/status-of-smallscale-water-supplies-in-the-who-european-region.-results-of-a-survey-conducted-under-the-protocol-on-water-andhealth-2016

5. WHO Water Safety Planning for Small Scale Community Water Supplies, ISBN 97892 41548427 (2012) https://www.who.int/water_sanitation_health/publications/smallcomm-water_supplies/en/

6. KWR Towards a Guidance Document for the implementation of a Risk Assessment for small water supplies in the European Union Overview of best practices https://circabc. europa.eu/sd/a/d097f8a9-e4ba-4800-89c809574a6f3d8e/TowardsBestPracticesDocument.pdf (2011) 
Környezetegészségügy - Eredeti közlemény / Environmental health - Original article

7. WHO Water safety plan: a field guide to improving drinking-water safety in small communities ISBN 978-92-890-5007-4 (2014) https://www.euro.who.int/en/countries/tajikistan/publications/water-safety-plan-a-field-guide-to-improving-drinking-water-safety-in-small-communities

8. WHO Taking policy action to improve small-scale water supply and sanitation systems ISBN 978-92-890-5160-6 https:// www.euro.who.int/en/health-topics/environment-and-health/water-and-sanitation/ publications/2016/taking-policy-action-toimprove-small-scale-water-supply-andsanitation-systems.-tools-and-good-practices-from-the-pan-european-region-2016

9. European Comisson Small Water Supplies, Expert Group under Directive meeting előadás, 2017

10. Humán felhasználású vizek informatikai rendszere (HUMVI) vízminőségi és vízellátási adatok (Adatszürés: 2018.03.30)
11. NNK által összeállított 2014-2016 évi ivóvízminőségi jelentés az Európai Bizottság részére

12. NNK kutatás (2018-2020), adatgyújtés a geológiaia eredetű fémek jelenlétére vonatkozóan a hazai ivóvízbázisokban (Adatszürés: 2020.04.06)

13. NNK által összeállított adatbázis az ivóvízbiztonsági tervek értékelésére vonatkozóan (Adatszürés: 2020.04.06)

14. NNK-KVL laboratóriumi adatbázis (Adatszúrés: 2020.04.06)

15. 201/2001 (XII.25) Kormányrendelet https:// net.jogtar.hu/jogszabaly?docid=a0100201. kor (Megtekintés: 2020.04.06.)

16. Országos Közegészségügyi Központ: Módszertani útmutató a saját célú ivóvízmúvek vízminőségi értékeléséhez valamint közegészségügyi szempontú szakmai tanácsadáshoz 2017 